\title{
A MiNHA FACULDADE DE LETRAS
}

Iria de Castro e Silva

UFMG

Era o ano de 1960 e eu, recém graduada em Letras Neolatinas, após um ano de estudo no exterior, entrara a fazer parte do quadro de professores da Faculdade de Filosofia da UMG.

Meu cargo era Instrutor de Ensino Superior e tinha como atribuição ministrar as aulas regulares de Língua Italiana e, além disso, assistir e acompanhar as aulas de Literatura que estavam a cargo de um professor estrangeiro, contratado pro tempore. Era um aprendizado maravilhoso, pois tratava-se de pessoa de alto nível intelectual, grande conhecedor de história da Arte, que se sentira atraído pelo Brasil e sobretudo por Minas Gerais, pela oportunidade de um contato direto com a arte barroca. Refirome a Ricardo Averini, que deixou marcas profundas na cultura mineira.

A Faculdade funcionava em três andares do Edifício Acaiaca $\left(19^{\circ}, 20^{\circ}\right.$ e $\left.21^{\circ}\right)$ e convivíamos com professores de diversas áreas: filosofia, história, geografia, pedagogia entre outras.

Dois anos depois, mudamo-nos para prédio próprio, situado à rua Carangola, no bairro Santo Antônio, cujo sétimo andar foi destinado aos cursos de Letras (Neolatinas, Clássicas e Germânicas). As turmas costumavam ser numerosas (de trinta a quarenta alunos) pois os cursos só funcionavam pela manhã.

Recebíamos por doze horas-aula a semanais e não havia obrigação de permanência na Instituição, mesmo porque não havia salas à disposição dos professores. Só podíamos contar com a Biblioteca, no andar térreo do prédio, que também era comum a todos.

Com a lei de Diretrizes e Bases da Educação, no ano de 1968, foram criadas as diversas Faculdades e Institutos oriundos do desmembramento da então Faculdade de Filosofia: Faculdade de Letras, Faculdade de Educação, Faculdade de Filosofia e Ciências Humanas, Instituto de Ciências Biológicas, e Instituto de Geociências.

No entanto, continuávamos a dividir o mesmo espaço, até que algumas unidades se transferiram para o Campus Pampulha.

Começamos a crescer, alargamos nossos horizontes com mais espaço, foram criados os novos Departamentos, começaram a funcionar os Cursos Noturnos, com muita procura, constituímos a nossa própria Congregação, de que tive a honra de participar como LivreDocente e Catedrática por nomeação.

Com a nova lei, cursos como o de Italiano perderam em número de alunos matriculados na Graduação, mas tínhamos oportunidade de oferecer matrícula como disciplina isolada ou eletiva, para os alunos da própria Faculdade ou de cursos afins. Oferecíamos também, regularmente, cursos semestrais de Lectura Dantis, frequentados por alunos e até mesmo professores de diferentes áreas de estudo. 
A esta altura, nosso Corpo Docente tinha se ampliado e já contávamos com gabinetes setoriais (pois trabalhávamos quase todos em regime de 40 horas semanais), onde podíamos estudar, trocar idéias ou fazer pequenas reuniões.

No setor de Italiano, nossa convivência era excelente, a figura o chefe ficava só no papel, ninguém tentava impor sua vontade, imperava o bom senso. Só as idades variavam: Maria Eneida e eu pertencíamos a uma faixa etária que não era a dos demais, Wander, Miquelina e Lúcia. Já o maestro Sergio Magnani, que, por algum tempo, trabalhou conosco, era o mais velho de todos e, pela sua grande cultura e maturidade, nos era de grande valia em nossas inúmeras dificuldades.

E assim caminhávamos, crescíamos, aprendíamos e ensinávamos coisas novas e o tempo foi passando, e para mim chegou a possibilidade da aposentadoria, que, apesar de desejada, não deixava de ser um pouco nostálgica. Só não o foi mais porque a própria Faculdade de Letras estava fechando suas portas da rua Carangola e transferindo-se para o Campus Pampulha.

Pairava no ar a agitação que precede uma grande mudança, um cheiro de novidade, um fazer e desfazer de malas e eu também entrei na onda e me senti como se estivesse indo também com os colegas, só mudando de sala, de bairro. Não foi penoso para mim levar meus livros e objetos pessoais para casa, se todos estavam também fazendo a mesma coisa.

A minha Faculdade de Letras continuou sendo aquela da rua Carangola, com suas rampas onde se encontrava todo mundo, seu horizonte de $180^{\circ}$ e seus corredores amplos, onde fui muito feliz.

Se tivesse de recomeçar, faria tudo de novo, do mesmo modo. 